\author{
Mirosław SOŁTYSIAK ${ }^{1}$
}

\title{
BUDŻET JEDNOSTKI SAMORZĄDU TERYTORIALNEGO A WIEDZA I AKTYWNOŚĆ LOKALNEJ SPOŁECZNOŚCI
}

\begin{abstract}
Funkcjonowanie jednostek samorządu terytorialnego jest bardzo ważnym zagadnieniem zarówno dla całego państwa, jak i dla statystycznego obywatela - mieszkańca danej gminy. To właśnie w ramach tych jednostek, na mocy obowiązującego prawa, mieszkańcy tworzą wspólnoty samorządowe, które są odpowiedzialne za zaspokojenie ich zbiorowych potrzeb wspólnotowych. Realizacjach zadań mających na celu zaspokojenie tych potrzeb ze względu na ograniczoną wielkość środków finansowych pozostających w dyspozycji poszczególnych jednostek samorządowych może wywoływać szereg kontrowersji nie tylko wśród decydentów, ale również wśród poszczególnych mieszkańców lub grup mieszkańców. Dlatego niezwykle istotnym zagadnieniem jest posiadanie przez obywateli odpowiedniego poziomu wiedzy o działalności tych jednostek - przede wszystkim o zasadach i przepisach na podstawie których następuje opracowywanie oraz realizacja ich budżetu. Władze jednostek samorządowych w ramach prowadzonego dialogu z mieszkańcami powinny dokładać szczególnych starań, aby przybliżyć im te zagadnienia, pobudzać ich aktywność oraz starać się włączyć jak największą liczbę mieszkańców do realizacji tych zadań. Przykładem dobrego działania w tym zakresie jest aktywizacja lokalnej społeczności poprzez umożliwienie jej współudziału w tworzeniu wydzielonej części budżetu jednostki samorządowej w ramach tzw. budżetu obywatelskiego.

W artykule przedstawiono wyniki badań ankietowych przeprowadzonych na mieszkańcach południowo-wschodniej Polski dotyczących stanu wiedzy społeczeństwa na temat budżetu jednostek samorządu terytorialnego oraz aktywności członków lokalnej społeczności w zakresie ich udziału w tworzeniu budżetu jednostek samorządowych.
\end{abstract}

Słowa kluczowe: budżet, jednostka samorządu terytorialnego, wiedza i aktywność, mieszkańcy

\section{WSTĘP}

Problematyka funkcjonowania jednostek samorządu terytorialnego powinna być istotna dla każdego członka lokalnej społeczności. Funkcjonowanie tych jednostek w mniej lub w bardziej zauważany sposób towarzyszy codziennemu życiu przeciętnego obywatela. To właśnie te podmioty są odpowiedzialne za zapewnienie mieszkańcom dostępu $\mathrm{m}$. in. do oświaty, opieki zdrowotnej czy kultury. Są również zobowiązane do stworzenia niezbędnej infrastruktury oraz systemu pomocy mieszkańcom. Na barkach tych podmiotów spoczywa

\footnotetext{
${ }^{1}$ Dr inż. Mirosław Sołtysiak, Zakład Finansów, Bankowości i Rachunkowości, Wydział Zarządzania, Politechnika Rzeszowska im. Ignacego Łukasiewicza, Al. Powstańców Warszawy 8, 35-959 Rzeszów; e-mail: miroslaw@prz.edu.pl
} 
ponadto odpowiedzialność za realizację części zadań związanych ze sprawami porządku i bezpieczeństwa publicznego ${ }^{2}$. Wszystkie te zadania jednostki samorządowe realizują w oparciu o posiadane ograniczone środki budżetowe, których podział często rodzi kontrowersje nie tylko wśród decydentów, ale również w lokalnych społecznościach.

Każdy pełnoletni obywatel może pośrednio wywierać wpływ na funkcjonowanie tych podmiotów poprzez udział w wyborach prezydenta, burmistrza czy wójta oraz w wyborze radnych, którzy w imieniu lokalnej społeczności uchwalają budżet jednostki samorządowej oraz sprawują nadzór nad prawidłowym funkcjonowaniem tych instytucji. W ostatnich latach niektóre jednostki samorządowe dają również możliwość swoim mieszkańcom bezpośredniego wpływu na to jakie zadania zaspokajające potrzeby lokalnych społeczności zostaną przyjęte do realizacji w danym roku poprzez udział w kształtowaniu wyodrębnionej części ich budżetu tzw. budżetu obywatelskiego.

Dlatego też każdy obywatel, aby mógł w pełni świadomie korzystać ze swoich praw, powinien posiadać przynajmniej podstawową wiedzę na temat zasad funkcjonowania budżetu jednostek samorządowych w ogóle oraz budżetu jednostki samorządu terytorialnego, na terenie której mieszka, w oparciu o który ta jednostka realizuje zadania za jakie jest odpowiedzialna.

\section{METODYKA I CEL BADAŃ}

W badaniach dotyczących „Stanu wiedzy społeczeństwa na temat budżetu jednostek samorządu terytorialnego oraz aktywności członków lokalnej społeczności w zakresie ich udziału w tworzeniu budżetu jednostek samorządowych" wykorzystano jako instrument pomiarowy kwestionariusz ankietowy. W badaniach ankietowych wzięła udział grupa 889 respondentów (w tym 447 kobiet $(50,28 \%)$ oraz 442 mężczyzn $(49,72 \%)$ ) powyżej 18. roku życia, którzy mieszkają w województwach południowo - wschodniej Polski ${ }^{3}$.

Podstawowym celem przeprowadzonych badań było podjęcie próby oceny znajomości zagadnień związanych z budżetem jednostek samorządu terytorialnego (j.s.t.) przez członków lokalnej społeczności oraz sprawdzenie stanu aktywności mieszkańców w tym zakresie.

\section{JEDNOSTKI SAMORZĄDU TERYTORIALNEGO A WIEDZA MIESZKAŃCÓW}

Na wstępie badań ankietowanym zadano pytania sprawdzające, mające na celu stwierdzenie, czy osoby uczestniczące w badaniach posiadają podstawową wiedzę, jakiego rodzaju jednostek one dotyczą.

Uzyskane wyniki z przeprowadzonych badań ankietowych pozwoliły na stwierdzenie, że większość osób w nich uczestniczących uważa, że posiada wiedzę na temat funkcjonowania jednostek samorządowych. Posiadanie takiej wiedzy zadeklarowało ponad $76 \%$ respondentów. Deklarację taką częściej składały kobiety $(78,08 \%)$ niż mężczyźni $(73,98 \%)$.

${ }^{2}$ Zadania, jakie ma realizować jednostka samorządowa w celu zaspokojenia zbiorowych potrzeb wspólnoty zostały określone w ustawie z dnia 8 marca 1990 r. o samorządzie gminnym (tekst jedn. Dz.U. z 2017 r., poz. 1875).

${ }^{3} \mathrm{~W}$ artykule zostały przedstawione wybrane zagadnienia z przeprowadzonych badań. 
Należy jednak podkreślić, że nie uczestniczące w badaniach kobiety ale mężczyźni wyżej oceniali poziom swojej wiedzę na ten temat (rys. 1). 27,83\% uczestniczących w badaniach mężczyzn oraz 22,5\% kobiet określiło swój poziom wiedzy jako „duży” lub „bardzo duży”. Natomiast 28,36\% kobiet oraz 20,79\% mężczyzn dokonując samooceny wskazało na odpowiedzi ,znikomy” lub „mały”.

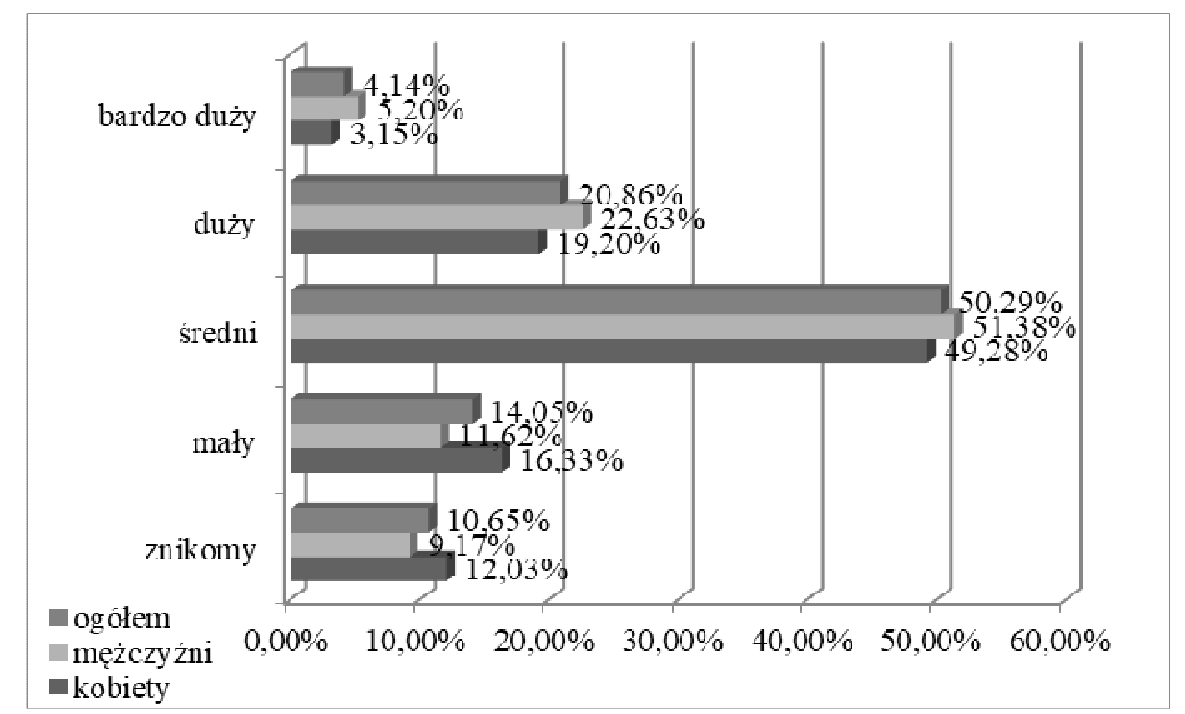

Rys. 1. Autoocena stanu wiedzy na temat funkcjonowania jednostek samorządu terytorialnego dokonana przez respondentów

Źródło: opracowanie na podstawie badań własnych.

W dalszej części badań, w celu weryfikacji dokonanej przez ankietowanych samooceny poziomu wiedzy, zadano im pytania dotyczące podstawowych informacji o jednostkach samorządu terytorialnego, tj. ,ilu szczeblowa jest struktura samorządu terytorialnego w Polsce” oraz „czy potrafią wymienić jednostki samorządu terytorialnego”.

Na pierwsze pytanie poprawnych odpowiedzi udzieliło $71,09 \%$ ankietowanych $(69,8 \%$ kobiet oraz $72,4 \%$ mężczyzn). Natomiast na drugie pytanie twierdząco odpowiedziało $81,89 \%$ respondentów (83\% kobiet oraz $80,77 \%$ mężczyzn). Ankietowani, którzy udzielili na to pytanie twierdzącej odpowiedzi, zostali w kolejnym pytaniu poproszeni o wymienienie jednostek samorządowych. Poprawnych odpowiedzi na nie udzieliło 92,72\% respondentów (92,45\% kobiet oraz 93\% mężczyzn). Tak więc poprawnie jednostki samorządowe w Polsce potrafiło wymienić $75,93 \%$ osób uczestniczących w badaniach - 76,73\% kobiet oraz $75,11 \%$ mężczyzn.

\section{ZNAJOMOŚĆ ZAGADNIEŃ ZWIĄZANYCH Z BUDŻETEM JEDNOSTKI SAMORZĄDU TERYTORIALNEGO WŚRÓD ANKIETOWANYCH}

Uczestniczące w badaniach osoby bardziej krytycznie oceniają swoją wiedzę w przypadku posiadanych informacji na temat funkcjonowania budżetu jednostki samorządowej (rys. 2). Tylko 34,76\% respondentów (w tym 36,24\% kobiet oraz 33,26\% mężczyzn) 
deklaruje, że posiada wiedzę na temat zagadnień związanych z przygotowywaniem i realizacją budżetu jednostki samorządu terytorialnego.
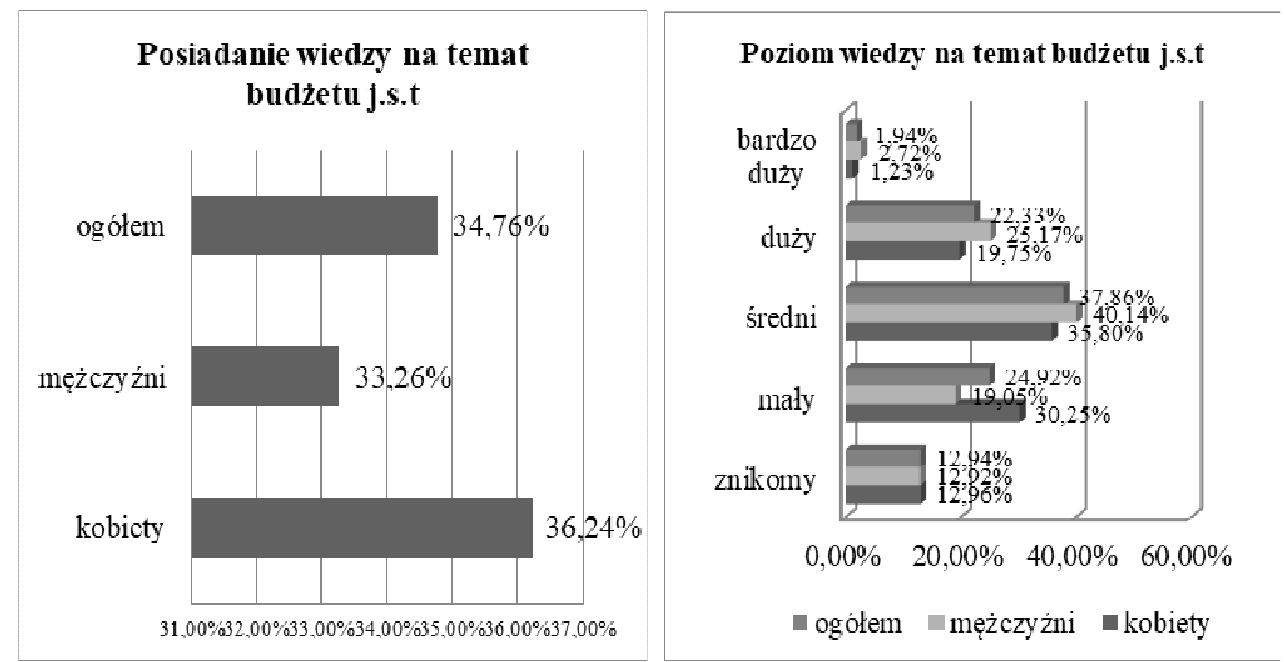

Rys. 2. Autoocena stanu wiedzy na temat przygotowania i realizacji budżetu jednostek samorządu terytorialnego dokonana przez respondentów

Źródło: opracowanie na podstawie badań własnych.

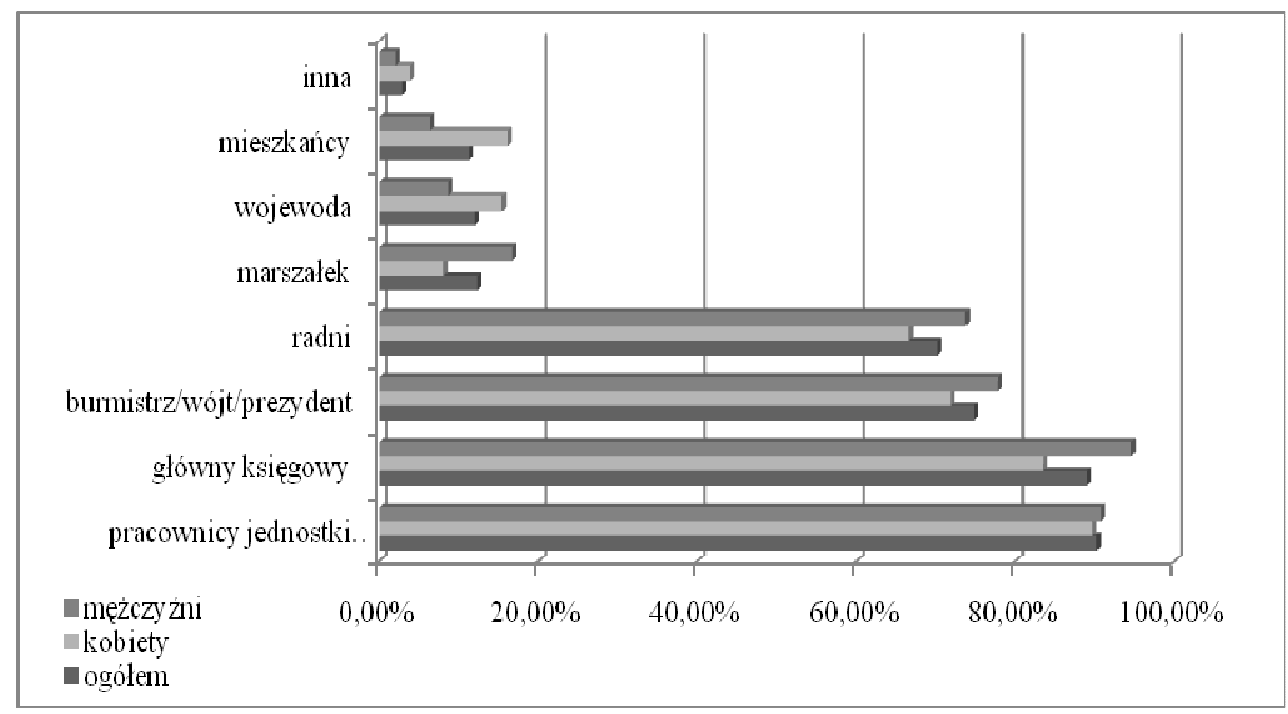

Rys. 3. Osoby odpowiedzialne za opracowanie projektu budżetu jednostki samorządu terytorialnego zdaniem respondentów

Źródło: opracowanie na podstawie badań własnych. 
Należy jednak zaznaczyć, że respondenci, którzy zadeklarowali znajomość zagadnień związanych z funkcjonowaniem budżetu jednostki samorządowej nie oceniają swojej wiedzy na ten temat wysoko (rys. 3). Tylko 1,94\% spośród tych ankietowanych (1,23\% kobiet oraz 2,72\% mężczyzn) wybrało odpowiedź „bardzo duży” a 22,33\% respondentów (19,75\% kobiet oraz 25,17\% mężczyzn) odpowiedź „duży”. Natomiast odpowiedź „mały” wskazało $24,92 \%$ ankietowanych (30,25\% kobiet oraz $19,05 \%$ mężczyzn) a odpowiedź „znikomy” 12,94\% respondentów (12,96\% kobiet oraz 12,92\% mężczyzn).

Następnie ankietowani, w celu określenia rzeczywistego stanu ich wiedzy na temat zagadnień związanych z funkcjonowaniem budżetu jednostek samorządu terytorialnego, zostali poproszeni o wskazanie osób, które ich zadaniem są odpowiedzialne za przygotowanie, zatwierdzenie oraz realizację budżetu tych jednostek.

Ponad 90\% ankietowanych (89,71\% kobiet oraz 90,72\% mężczyzn) było zdania, że osobami odpowiedzialnymi za opracowanie projektu budżetu jednostki samorządowej są jej pracownicy (rys. 4). Prawie $89 \%$ respondentów (83,44\% kobiet oraz 94,57\% mężczyzn) wskazało, że osobą bezpośrednio odpowiedzialną za przygotowanie budżetu j.s.t. jest skarbnik/główny księgowy, a 74,8\% ankietowanych (71,81\% kobiet oraz 77,83\% mężczyzn) wskazało na „burmistrza/wójta/prezydenta”. Ponad 70\% uczestników badań $(66,67 \%$ kobiet oraz $73,75 \%$ mężczyzn) uważało, że prace nad projektem budżetu należą do obowiązków radnych. Trzeba również zaznaczyć, że co dziesiąty respondent uważał, że w pracach nad przygotowaniem projektu budżetu uczestniczą również mieszkańcy. Interesujący jest fakt, że na udział mieszkańców w przygotowaniu projektu budżetu jednostki samorządowej wskazało aż 16,11\% kobiet i tylko 6,33\% mężczyzn.

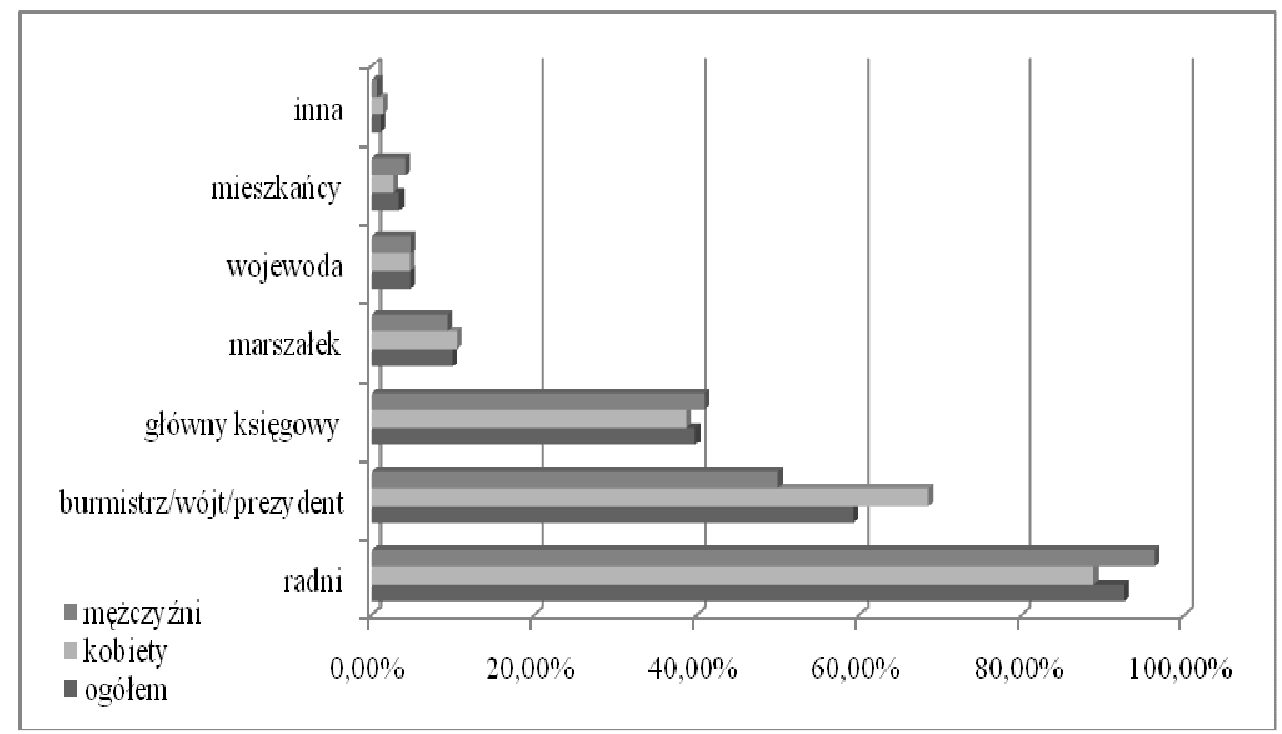

Rys. 4. Osoby zatwierdzające budżet jednostek samorządu terytorialnego zdaniem respondentów Źródło: opracowanie na podstawie badań własnych. 
Natomiast zdaniem 92,58\% uczestników badań odpowiedzialność za uchwalenie budżetu spoczywała na radnych (rys. 4). Takiego zdania było $88,81 \%$ kobiet oraz $96,38 \%$ mężczyzn. 59,28\% ankietowanych twierdziło, że osobą odpowiedzialną za zatwierdzenie budżetu jednostki samorządowej jest „,burmistrz/wójt/prezydent” a 39,82\% respondentów wskazało na skarbnika/głównego księgowego.

Należy zaznaczyć, ze uczestniczące w badaniach kobiety $(68,45 \%)$ częściej niż mężczyźni (50\%) wskazywały na „burmistrza/wójta/prezydenta”. Natomiast mężczyźni (40,95\%) częściej niż kobiety $(38,7 \%)$ wymieniali skarbnika/głównego księgowego. Co dziesiąty respondent twierdził, że odpowiedzialność w tym zakresie spoczywa na marszałku a co dwudziesty ankietowany wskazał na wojewodę.

Z kolei udzielając odpowiedzi na pytanie, kto jest odpowiedzialny za realizację budżetu jednostki samorządowej uczestnicy badań na pierwszym miejscu wskazali „burmistrza/wójta/ prezydenta" (rys. 5). Takiego zdania było aż 99,55\% ankietowanych (99,78\% kobiet oraz 99,32\% mężczyzn). Na drugim miejscu respondenci wymieniali radnych, których wskazało $94,15 \%$ badanych $(91,27 \%$ kobiet oraz $97,06 \%$ mężczyzn). Na kolejnych miejscach ankietowani wskazywali skarbnika/głównego księgowego $(88,41 \%)$ oraz pracowników jednostki samorządowej $(75,48 \%)$.

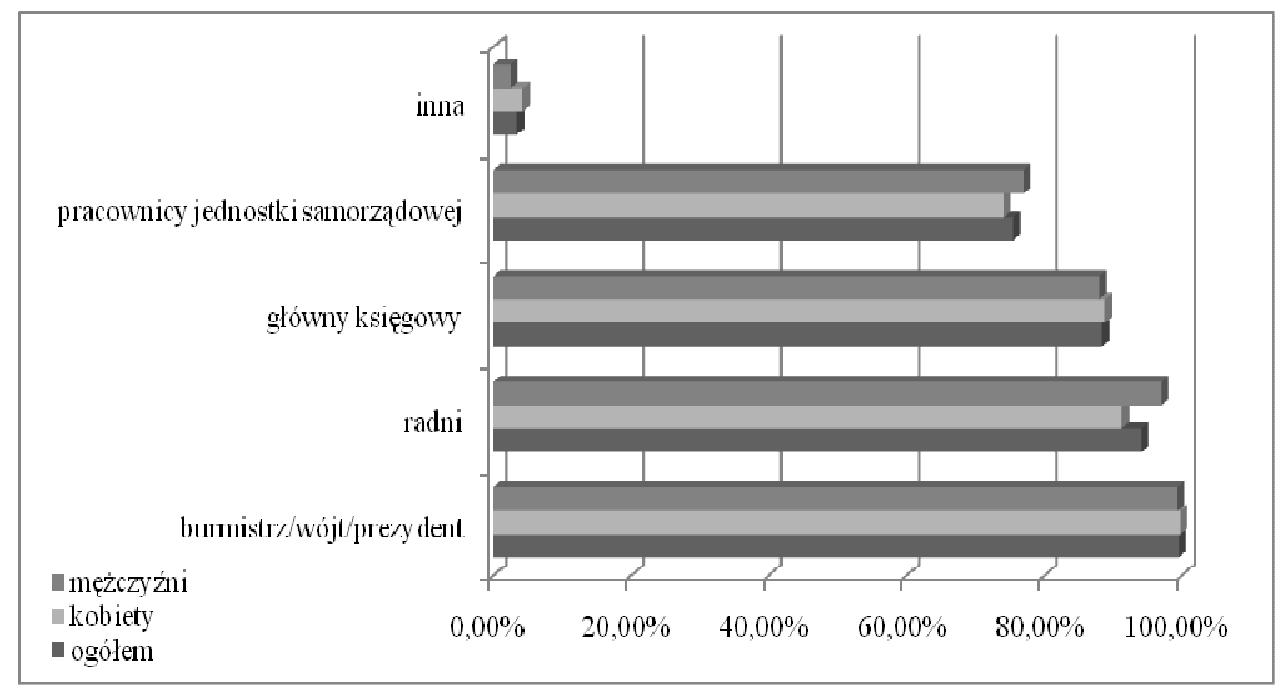

Rys. 5. Osoby odpowiedzialne za realizację budżetu jednostek samorządu terytorialnego zdaniem respondentów

Źródło: opracowanie na podstawie badań własnych.

W dalszej części badań ankietowani zostali poproszeni o wymienienie źródeł, z jakich pochodzą środki finansowe wchodzące w skład budżetu jednostki samorządowej (rys. 6). Uczestnicy badań wskazali na dwa podstawowe źródła tych środków, tj. środki z budżetu państwa oraz podatki. Środki pochodzące z budżetu państwa zostały wskazane przez $78,06 \%$ ankietowanych (76,28\% kobiet oraz 79,86\% mężczyzn). Natomiast podatki wymieniło $75,03 \%$ respondentów (71,14\% kobiet oraz 78,96\% mężczyzn). 


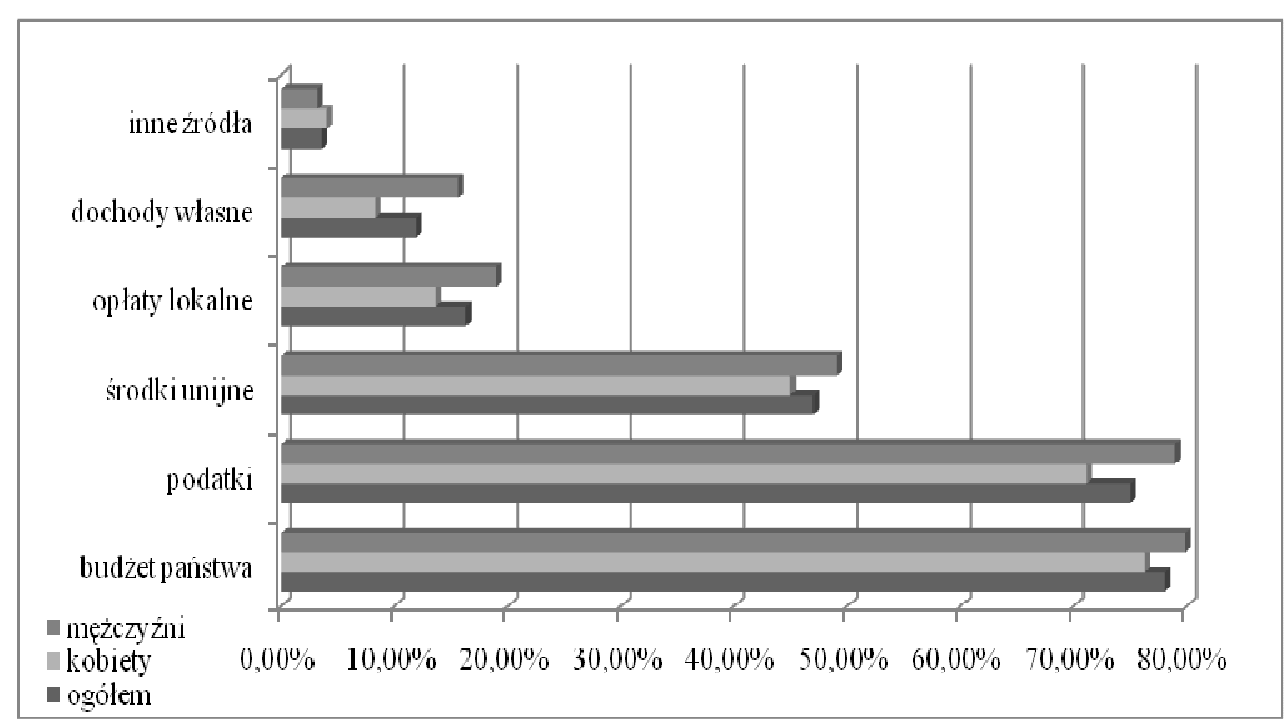

Rys. 6. Źródła, z jakich pochodzą środki finansowe tworzące budżet jednostek samorządu terytorialnego zdaniem respondentów

Źródło: opracowanie na podstawie badań własnych.

Jako trzecie źródło środków finansowych pozyskiwanych do swojego budżetu przez jednostki samorządu terytorialnego ankietowani wymieniali środki unijne $(47,02 \%)$. Zostały one wskazane przez 44,97\% kobiet oraz 49,09\% mężczyzn.

Zdaniem części uczestników badań w budżecie jednostki samorządu terytorialnego znajdują się również środki pochodzące z opłat lokalnych oraz dochodów własnych. Opłaty lokalne zostały zakwalifikowane jako środki budżetowe przez 16,31\% ankietowanych a dochody własne przez $11,92 \%$ respondentów. Należy podkreślić, że w obu przypadkach częściej te środki wymieniali mężczyźni niż kobiety. Opłaty lokalne wymieniło odpowiednio $13,65 \%$ kobiet oraz $19 \%$ mężczyzn, a dochody własne wskazało 8,28\% kobiet oraz $15,61 \%$ mężczyzn.

Następnie uczestnicy badań zostali poproszeni o wskazanie celów, na jakie powinny zostać przeznaczone środki finansowe znajdujące się w budżetach jednostek samorządowych (rys. 7). Zdecydowana większość badanych $(92,99 \%)$ wskazała na realizację zadań związanych z oświatą i wychowaniem. Na kolejnych miejscach ankietowani umieścili ochronę zdrowia $(45,67 \%)$ oraz pomoc społeczną (42,52\%). Należy zaznaczyć, że kobiety częściej wskazywały na ochronę zdrowia (48,55\% kobiety oraz 42,76\% mężczyźni), a mężczyźni na pomoc społeczną (38,25\% kobiety oraz 45,47\% mężczyźni).

Co czwarty ankietowany uważał, że środki pochodzące z budżetu jednostek samorządowych powinny być przeznaczone na „kulturę i ochronę dziedzictwa narodowego” a co piąty respondent przeznaczyłby je na ochronę środowiska.

Co szósty uczestnik badań wydatkowałby je na „gospodarkę komunalną”, a co siódmy ankietowany na ,gospodarkę mieszkaniową". 10,24\% respondentów wskazywało, że jednostki samorządowe powinny również wydawać posiadane środki na zadania związane z szeroko rozumianą działalnością promocyjną jednostki. Odpowiedź tę częściej wskazywali mężczyźni $(12,9 \%)$ niż kobiety $(7,61 \%)$. 


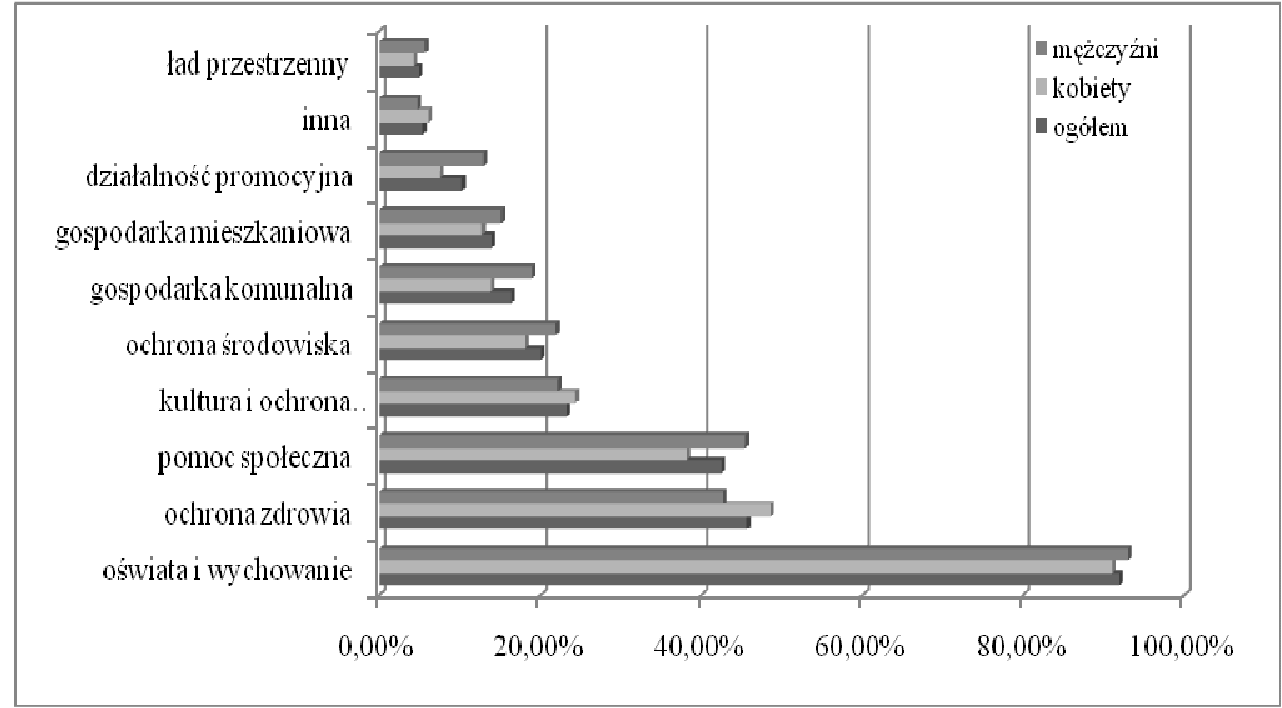

Rys. 7. Cele, na jakie powinny być przeznaczone środki z budżetu jednostek samorządu terytorialnego zdaniem respondentów

Źródło: opracowanie na podstawie badań własnych.

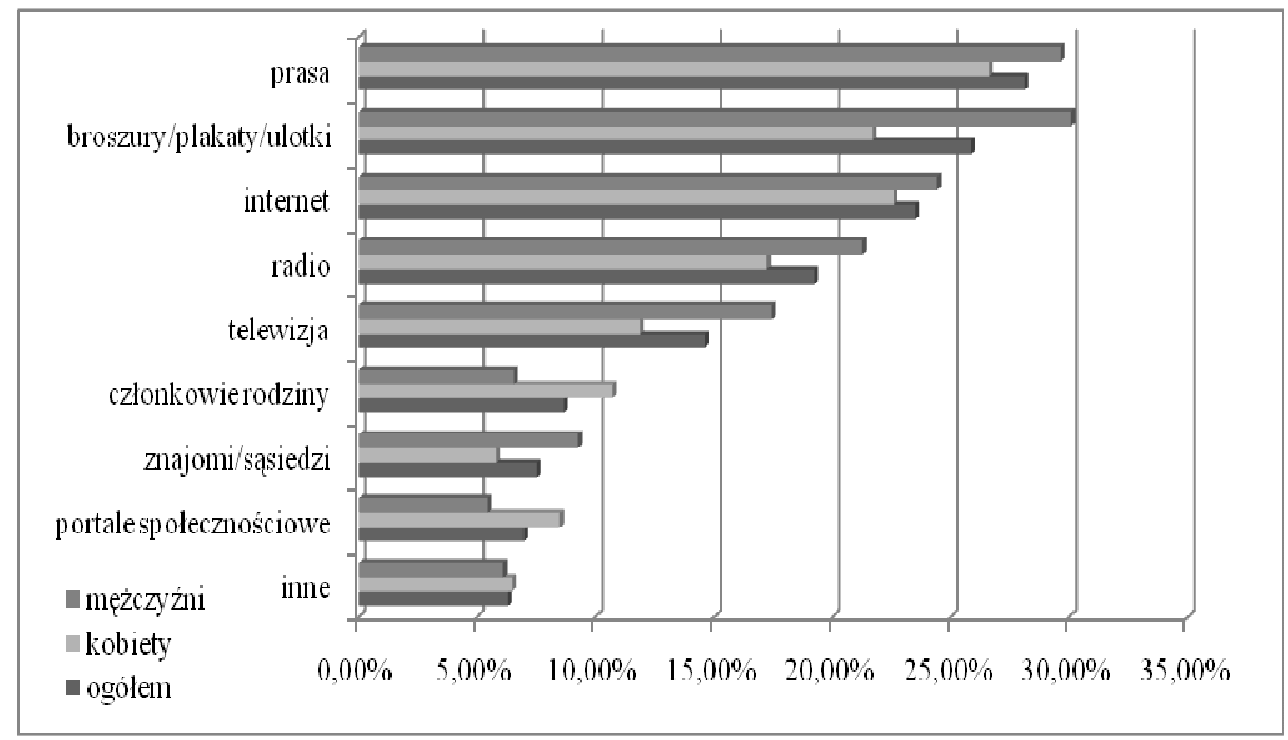

Rys. 8. Źródła z jakich ankietowani pozyskują informacje na temat budżetu jednostki samorządu terytorialnego

Źródło: opracowanie na podstawie badań własnych. 


\section{5. ŹRÓDŁA INFORMACJI NA TEMAT FUNKCJONOWANIA BUDŻETU JEDNOSTEK SAMORZĄDU TERYTORIALNEGO}

Uczestniczący w badaniach respondenci zadeklarowali, że swoją wiedzę na temat zagadnień związanych z budżetem jednostek samorządu terytorialnego czerpią przede wszystkim z prasy $(28,12 \%), \mathrm{z}$,broszur/plakatów/ulotek” $(25,87 \%)$ oraz z Internetu $(23,51 \%)$.

Na kolejnych miejscach jako źródło pozyskiwania informacji na ten temat ankietowani wskazali radio $(19,23 \%)$ oraz telewizję $(14,62 \%)$. Wśród uczestników badań była również grupa respondentów, która wiedzę na temat budżetu jednostki samorządu terytorialnego opierała na informacjach uzyskanych od członków rodziny $(8,66 \%)$ oraz od sąsiadów i znajomych $(7,54 \%)$.

\section{AKTYWNOŚCI CZŁONKÓW LOKALNEJ SPOŁECZNOŚCI W ZAKRESIE UDZIALU W TWORZENIU BUDŻETU JEDNOSTEK SAMORZĄDOWYCH}

Na wstępie badań dotyczących aktywności członków lokalnej społeczności w pracach związanych z budżetem jednostek samorządowych zadano ankietowanym pytanie „czy ich zdaniem mieszkańcy powinni posiadać możliwość bezpośredniego wpływu na budżet jednostki samorządu terytorialnego, którą zamieszkują".

Zdecydowana większość ankietowanych jest zdania, że mieszkańcy powinni posiadać możliwość bezpośredniego wpływu na kształt budżetu jednostki samorządowej w której mieszkają (rys. 9). Potwierdzeniem tego jest fakt, że odpowiedzi „zdecydowanie tak” oraz „raczej tak” wybrało łącznie 76,71\% ankietowanych $(72,03 \%$ kobiet oraz $81,45 \%$ mężczyzn). Natomiast odpowiedzi „zdecydowanie nie” oraz „raczej nie” wskazało łącznie tylko 13,16\% respondentów (14,32\% kobiet oraz 11,99\% mężczyzn).

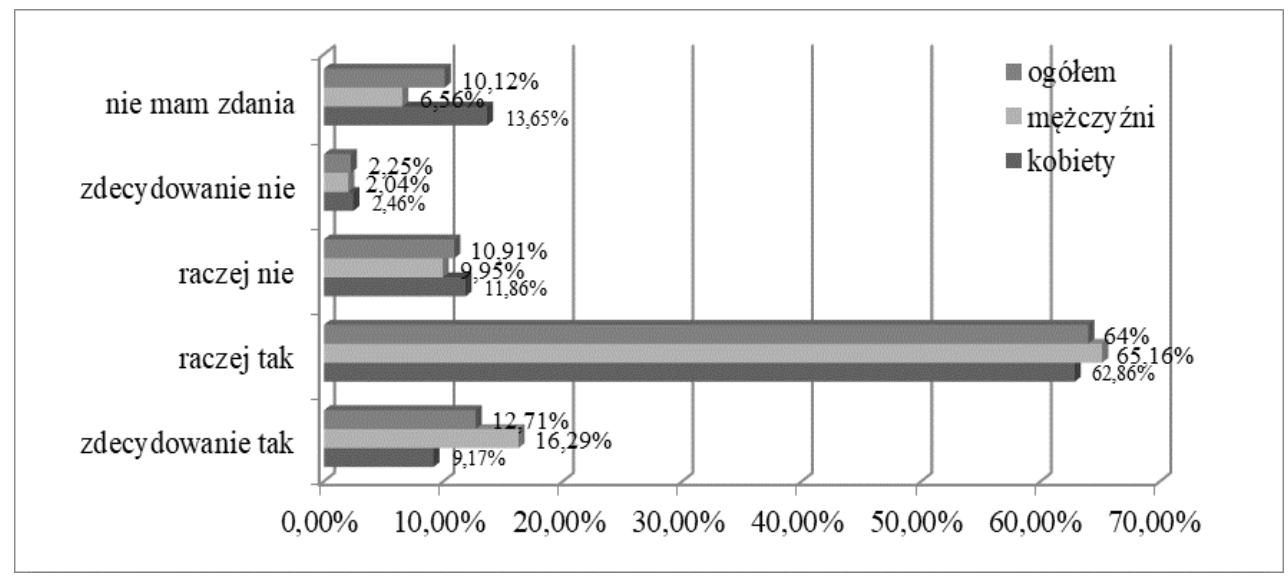

Rys. 9. Opinie respondentów na temat czy mieszkańcy powinni posiadać możliwość bezpośredniego wpływu na budżet jednostki samorządu terytorialnego, którą zamieszkują.

Źródło: opracowanie na podstawie badań własnych. 
Niestety, odpowiedzi te nie przekładają się na aktywność wśród ankietowanych w tym zakresie. Tylko nie całe 10\% uczestników badań zadeklarowało, że uczestniczyło w jakichkolwiek działaniach związanych $\mathrm{z}$ funkcjonowaniem budżetu jednostki samorządu terytorialnego. 5,62\% ankietowanych zadeklarowało, że był to udział w spotkaniu lokalnej społeczności. $4,72 \%$ respondentów uczestniczyło $\mathrm{w}$ spotkaniu na ten temat $\mathrm{z}$ radnymi, a 3,26\% badanych brało udział w spotkaniu z „,burmistrzem/prezydentem/wójtem”. Zaledwie $0,11 \%$ uczestników badań zadeklarowało, że w sposób czynny wpływało na kształt budżetu jednostki samorządowej poprzez zgłoszenie propozycji zadania do realizacji.

\subsection{Budżet partycypacyjny a aktywność mieszkańców}

Idea budżetu partycypacyjnego została opracowana w południowoamerykańskim mieście Porto Alegre blisko trzydzieści lat temu ${ }^{4}$. Sukces jaki odniosła ta idea w mieście Porto Alegre stał się w kolejnych latach impulsem do jej wprowadzenia przez ok. 130 samorządów miast południowoamerykańskich ${ }^{5}$ oraz liczne samorządy z innych kontynentów.

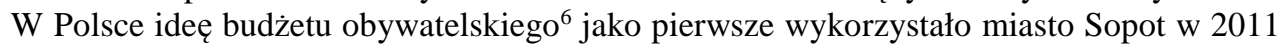
roku.

Od 2012 r. kolejne jednostki samorządowe na swoim terenie wykorzystują tę ideę można nawet powiedzieć, że w Polsce powstała moda na współudział obywateli w uchwalaniu wyodrębnionej części budżetu jednostki samorządowej poprzez głosowanie na budżet obywatelski.

Uczestnicy badań zostali poproszeniu o odpowiedź na pytanie, czy znana jest im idea budżetu partycypacyjnego. W analizowanej grupie znajomość tych zagadnień zadeklarowało $23,17 \%$ badanych. Należy jednak podkreślić, że o ile w segmencie ankietowanych, w których w miejscu zamieszkania realizowana jest idea budżetu partycypacyjnego wiedzę o nim deklarowało aż 79,11\% respondentów to wśród badanych zamieszkujących miejscowości, gdzie budżet partycypacyjny nie jest wykorzystywany przez władze samorządowe wiedzę taką deklarowało tylko $11,08 \%{ }^{7}$.

Trzeba również podkreślić, że pomimo braku znajomości przez większość ankietowanych zagadnień związanych z budżetem partycypacyjnym oraz stosunkowo niskiego poziomu wiedzy na ten temat wśród osób, które deklarowały, że znają tą idę̨ ${ }^{8}$ ponad połowa

${ }^{4}$ B. Wampler, A guide to participatory budgeting, 2000 [online] (dostęp: 31.05.2016). http://www.internationalbudget.org/wp-content/uploads/A-Guide-to-Participatory-Budgets.pdf.

B. Wampler, Participatory Budgeting in Brazil. Contestation, Cooperation, and Accountability. The Pennsylvania State University Press, University Park, Pennsylvania 2007.

572 Frequently Asked Questions about Participatory Budgeting. UN-HABITAT, Quito 2004, s. 11.

${ }^{6}$ W Polsce idea oparta o budżet partycypacyjny nazywana jest budżetem obywatelskim.

7 Dla porównania w przeprowadzonych badaniach na temat "Aktywności członków lokalnej spoteczności miasta Rzeszowa w zakresie budżetu partycypacyjnego" ponad 77\% respondentów (w tym 76,15\% kobiet oraz 79,43\% mężczyzn) zadeklarowało, że posiada wiedzę na temat funkcjonowania budżetu partycypacyjnego. Szerzej zob. M. Sołtysiak, M. Suraj, Engagement of local community members in terms of participatory budgeting based on municipality of Rzeszów. Proceedings $14^{\text {th }}$ International Scientific Conference "Economic Policy in the European Union Member Countries". Silesian University, Karvina 2016

8 60,19\% badanych określiło swój poziom wiedzy na temat budżetu partycypacyjnego jako „znikomy” a 22,33\% respondentów jako „mały”. 
uczestników badań $(57,03 \%)$ uważa, że mieszkańcy powinni posiadać możliwość uczestnictwa w tej formie współrządzenia (rys. 10). A 44,21\% ankietowanych $(44,07 \%$ kobiet oraz 44,34\% mężczyzn) zadeklarowało, że w przyszłości zamierza brać udział w głosowaniach na budżet partycypacyjny.

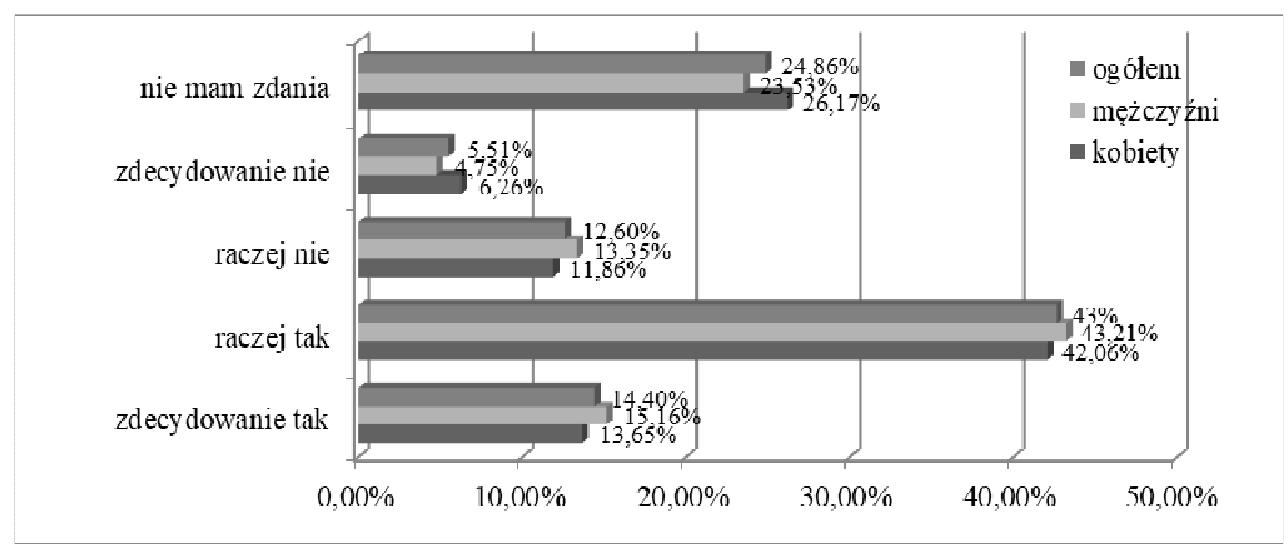

Rys. 10. Opinie respondentów na temat czy mieszkańcy powinni bezpośrednio uczestniczyć w uchwalaniu budżetu jednostki samorządowej poprzez udział w głosowaniu na budżet obywatelski (partycypacyjny)

Źródło: opracowanie na podstawie badań własnych.

\section{PODSUMOWANIE}

Przeprowadzone badania pozwalają stwierdzić, że znacząca większość respondentów (76\%) deklaruje, że zagadnienia związane z funkcjonowaniem jednostek samorządu terytorialnego nie są im obce. Należy jednak stwierdzić, że chociaż ankietowani stosunkowo wysoko oceniają poziom swojej wiedzy na ten temat to co czwarty z uczestników badań nie potrafił poprawnie odpowiedzieć na pytania sprawdzające. W przypadku bardziej szczegółowych zagadnień dotyczących tworzenia i realizacji budżetu jednostki samorządowej tylko co trzeci uczestnik badań deklarował, że posiada wiedzę na ten temat. Trzeba równocześnie zaznaczyć, że osoby te w większości określają jej poziom na jako niski.

Analiza otrzymanych wyników pozwala również stwierdzić, że chociaż zdecydowana większość członków społeczności lokalnych uważa, że problematyka zarządzania finansami jednostek samorządowych jest zagadnieniem bardzo istotnym dla ich codziennego życia to nie zadają sobie oni trudu aby pozyskać szczegółowe informacje na ten temat.

Analizując aktywność członków lokalnych społeczności w udziale w tworzeniu i realizacji budżetów jednostek samorządowych należy stwierdzić, że zdecydowana większość respondentów była zdania, że mieszkańcy powinni mieć możliwość bezpośredniego wpływu na kształt budżetu jednostki samorządowej na terenie której mieszkają. Niestety, zdanie to nie przekładało się na aktywność ankietowanych. Tylko co dziesiąty uczestnik badań podjął jakikolwiek trud aby aktywnie uczestniczyć w tych działaniach. Można 
jednak mieć nadzieję że w najbliższych latach aktywność ta może znacząco wzrosnąć pod warunkiem wprowadzenia przez kolejne jednostki samorządowe idei budżetu obywatelskiego ${ }^{9}$. Potwierdzeniem tego może być fakt, że wśród uczestników badań prawie $60 \%$ respondentów twierdziło, że mieszkańcy powinni mieć taką możliwość współtworzenia budżetu a prawie $45 \%$ deklarowało, że wzięłoby udział w takim głosowaniu.

\section{LITERATURA}

[1] 72 Frequently Asked Questions about Participatory Budgeting. UN-HABITAT, Quito 2004.

[2] Sołtysiak M., Suraj M., Engagement of local community members in terms of participatory budgeting based on municipality of Rzeszów. Proceedings $14^{\text {th }}$ International Scientific Conference "Economic Policy in the European Union Member Countries". Silesian University, Karvina, 2016.

[3] Wampler B., A guide to participatory budgeting. http://www.internationalbudget.org/wpcontent/uploads/A-Guide-to-Participatory-Budgets.pdf.

[4] Wampler B., Participatory Budgeting in Brazil. Contestation, Cooperation, and Accountability. The Pennsylvania State University Press, University Park, Pennsylvania 2007.

[5] Ustawa z dnia 8 marca 1990 r. o samorządzie gminnym (tekst jedn. Dz.U. z 2017 r., poz. 1875).

\section{BUDGET OF LOCAL GOVERNMENT UNIT AND KNOWLEDGE AND ACTIVITY OF THE MEMBERS OF THE LOCAL COMMUNITY}

The functioning of local government units is a very important issue both for the whole country as well as for a statistical citizen, a resident of a given commune. It is precisely within these units, by virtue of applicable law, that local residents form self-governing communities that are responsible for meeting their collective community needs. Because of the limited amount of funds available to particular local government units, the achievement of the tasks whose aim is to satisfy these needs may cause a great number of controversies not only among the decision-makers but also among individual residents or the groups of residents. Therefore, as far as citizens are concerned, having an appropriate level of knowledge concerning the operation of these units, mainly about the rules and regulations under which both the establishment and achievement of their budget are made, is an extremely important issue. The authorities of self-government units on the basis of the dialogue with the residents should make special efforts to bring these issues closer, stimulate their activity and try to involve as many people as possible in the implementation of these tasks. As an example of a good action in this area is the activation of the local community by allowing them to participate in the creation of a separate part of the self-government unit budget within so called civic budget.

The article presents the results of the survey conducted on the residents of south-eastern part of Poland regarding the state of knowledge of the society concerning the budget of local

\footnotetext{
${ }^{9}$ Budżet obywatelski daje bowiem możliwość z jednej strony na zapoznanie się przez mieszkańców ze sposobami zarządzania finansami jednostki samorządowej. Z drugiej zaś strony przenosi część odpowiedzialności za podział środków budżetowych na obywateli. Tak więc z jednej strony posiada walory edukacyjne a z drugiej strony poprzez zbiorową odpowiedzialność za wspólne dobro, pomaga w tworzeniu więzi w lokalnej społeczności. Zwiększając poczucie odpowiedzialności poszczególnych obywateli za miejsce zamieszkania.
} 
government units as well as the activity of the members of the local community in terms of their participation in the creation of the budget of local government units.

Keywords: budget, territorial self-government unit, knowledge and activity, inhabitants.

DOI: 10.7862/rz.2017.hss.75

Przestano do redakcji: lipiec 2017 r.

Przyjęto do druku: grudzień 2017 r. 
